\title{
Financialization and Organizational Changes in Multinational Enterprises
}

Angelo Salento, Giovanni Masino and Domenico Berdicchia

\section{(2) OpenEdition \\ Journals}

Electronic version

URL: https://journals.openedition.org/rei/5710

DOI: $10.4000 /$ rei.5710

ISSN: $1773-0198$

Publisher

De Boeck Supérieur

\section{Printed version}

Date of publication: 1 December 2013

Number of pages: 145-176

ISBN: 9782804185701

ISSN: 0154-3229

\section{Electronic reference}

Angelo Salento, Giovanni Masino and Domenico Berdicchia, "Financialization and Organizational Changes in Multinational Enterprises", Revue d'économie industrielle [Online], 144 | 4e trimestre 2013, Online since 01 December 2015, connection on 07 June 2022. URL: http://journals.openedition.org/ rei/5710 ; DOl: https://doi.org/10.4000/rei.5710 


\title{
FINANCIALIZATION AND ORGANIZATIONAL CHANGES IN MULTINATIONAL ENTERPRISES
}

\author{
Angelo Salento (University of Salento), Giovanni Masino (University of Ferrara), \\ Domenico Berdicchia (University of Ferrara)
}

Mots clés : Gouvernement d'entreprise, structure financière, stratégie et performance.

Keywords: Corporate Governance, Financial Structure, Strategy and Performance.

\section{INTRODUCTION 1}

How do we interpret the significant organizational transformations that characterized most enterprises in the last thirty years? So far, the prevailing explanation is that such changes emerged as the rational answer to industrial and productive problems: the need to face an increasing instability of the goods and services markets. In this paper we propose a different interpretation. We argue that such transformations are better explained by focusing on the pressure exercised by financial markets. We call this process "financialization" of enterprises - that is, a progressive adjustment of all enterprises' relevant dimensions (formal control, accounting, strategy, structures, work organization, personnel policies, internal culture, etc.) in order to accommodate an increasing orientation

I While this paper is the outcome of a shared research and reflection effort by the authors, the writing of the single paragraphs can be attributed in the following way. Angelo Salento wrote paragraphs I, 3 and 4; Domenico Berdicchia wrote paragraphs 5 and 6; Giovanni Masino wrote paragraphs 2, 7 and 8. 
towards financial accumulations. Many authors already noticed the development of a sort of "paper economy" and, in parallel, an increasingly "flexible" productive economy (Harvey, 1990). However, only in the last decade the tight connection between the two has been observed. Nonetheless, financialization is still a somewhat vague construct. Definitions oscillate between purely quantitative descriptions of how financial operations have surged dramatically over the years, and larger scale, system-level narratives, such as the one proposed by Luciano Gallino (20II). In our perspective, the idea of "financialization of enterprises" alludes not only to the final outcome of a large, system-level transformation, but also to the process that generated such outcome - that is, the normative, institutional and cultural mutations that built and supported a significant continuity between the world of production and the financial markets. It is worth emphasizing that we are not proposing a mono-causal, deterministic view. We refer to financialization as an analytical construct, which is useful in order to focus on one process that, together with many others, may be relevant in describing and explaining the significant economic and organizational changes that occurred in the last decades. In the following paragraphs we will summarize how such construct can be utilized to explain organizational changes in relation to alternative narratives; we will provide an analytical framework in order to understand the possible connections between financialization and organizational changes; we will show the results of our empirical research, which relied on two different methodologies. Finally, we will briefly discuss the results.

\section{THE RHETORIC AND CRITIQUE OF POST-FORDISM}

Post-fordism is one the key words upon which the history of social transformations in the last thirty years has been narrated in social sciences and public discourses. Critical interpretations of the "Post-fordist" idea are also available. For example, there is a large movement of research and studies, under the label of "Critical Management Studies", in which the most common apologetic representations of the Post-fordist transition are sharply criticized by emphasizing the strong continuity with Fordism. However, even these critical perspectives do not question the mainstream idea according to which the Post-fordist logic is essentially an industrial, 
market-based one. In one of the most influential mainstream interpretations, Piore and Sabel (1984) proposed the idea of a radical transformation in which the Fordist industrial system was replaced by a new "regime", thanks to a number of different processes, such as: the saturation of national markets - which pushed companies to globalize their operations - and the so called "double convergence" (Sabel, 1989) which lead to a new kind of capitalism, called by the authors "flexible specialization". Even more "market-centric" and "techno-centric" is the interpretation provided by the managerial literature, in which the need for flexibility and quality paved the way for new managerial practices like Total Quality Management (Deming, 1986), Business Process Reengineering (Hammer, Champy, 1993; Short, Davenport, 1990) and Lean Production (Womack, James, Ross, I990). These new practices implied a complete abandonment of the Fordist-Tayloristic orthodoxy: the use of teamwork instead of tasks' atomization; the use of empowerment and increased responsibility for workers instead of direct supervision; decentralization of decision prerogatives instead of centralization; a focus on outcomes and the "horizontal" dimension of coordination instead of a focus on procedures and vertical control. All these major changes at various analytical levels (from "macro" to "micro"), under the new label of Post-Fordism, are supposed to be consistent, according to the mainstream readings, to the new "requests" of the globalized markets and production systems. Thus, what we observe is largely depicted as a major, large scale industrial and organizational revolution, which - just like in the case of Fordism - is accompanied by very radical social and cultural changes as well. This is also very consistent with the literature emphasizing the "network-ization" of production (Powell, 1990), in which companies outsource large portions of their activities in order to focus on their "core business" by managing strategically external networks and partners. Again, this is largely seen as a transformation in the name of industrial and organizational efficiency, supported by the theoretical perspective of organizational economics (Williamson, 1986). Finally, "neo-schumpeterian" accounts (Freeman, 1984) also focus on market efficiency as the main drive for these changes, essentially guided by technological evolution and innovation.

As we already anticipated, even anti-mainstream interpretations do not offer a very different conceptual foundation. According to the "regulation school" (Amin, I995; Boyer, I990; Aglietta, 1979), for instance, the passage 
from Fordism to Post-Fordism can be explained in terms of a different "regulation regime" which, at the same time, transformed most institutions but also ensured the continuity of the capitalistic system. Again, at the origin of the transformation lies the crisis of mass production, which required new industrial and organizational arrangements. Just recently these authors turned their attention to the relevance of financial markets in determining this historical transformation (Aglietta, Rebérioux, 2005; Boyer, 20II). A similar trajectory was followed by David Harvey. In his classic book "The Condition of Post-modernity", the financial system is described as a facilitator for a demand-based transformation, which ultimately depends on the saturation and instability of the goods' markets. More recently, Harvey turned his attention to financial dynamics as a major explanatory element (Harvey, 2005, 20I0). Finally, the "Critical Management Studies" approach (Wilmott, Alvesson, 1992) challenges on multiple accounts the Post-fordist rhetoric, especially in terms of its selfproclaimed embracing of decentralization, empowerment and democratization of the workplace. These critical interpretations focused instead on power as the most important concept. Companies are conceived as domination structures (Odih, Knights, 2009; Boreham, 1992). However, even the CMS literature puts very little emphasis on the possible relation between the financialization process and the Post-fordist "revolution".

Thus, we believe there is still a fundamental interpretative gap to be filled. The literature is very helpful in order to better understand the deep, inherent contradictions and the rhetorical ambiguities that characterize the current managerial practices, and the Post-fordist system as a whole (Masino, 2005). They are also very useful to remind us that power dynamics represent an essential ingredient in order to understand both micro-level and macro-level managerial and economic transformations. However, in this paper we propose that a careful consideration of the intersection between the financial and the industrial / organizational dimensions is crucial in order to provide a more complete, convincing and accurate picture of the changes that happened in the business and economic world in the last thirty years. In the next section, we will briefly show some data about the relevance and the pervasiveness of the financialization phenomenon. 


\section{FINANCIALIZATION OF THE ECONOMY AND FINANCIALIZATION OF ENTERPRISES}

In a recent Critical Management Studies Conference (Naples, Italy, July 20II) one of the tracks had the following title: "Is financialization a meaningful -ization?". For our purposes, this is a crucial question. If what we call financialization was not a relevant phenomenon per se, then it would be hard to claim its significance for the explanation of the organizational changes and arrangements occurring within enterprises. As we already stated, financialization can be conceived in different ways. A first, more general concept of financialization refers to the increase of the absolute and relative value of financial transactions, within a situation of widespread de-regulation of capital movements, and to the growth of the relevance of financial institutions and élites, both at the national and international level (Epstein, 2006; Palley, 2007). In other words, we refer to the growing importance of financial activities as sources of profits (Krippner, 20II). This construct can be measured in a variety of ways.

Figure 1. Total value of stock trades in billions of dollars

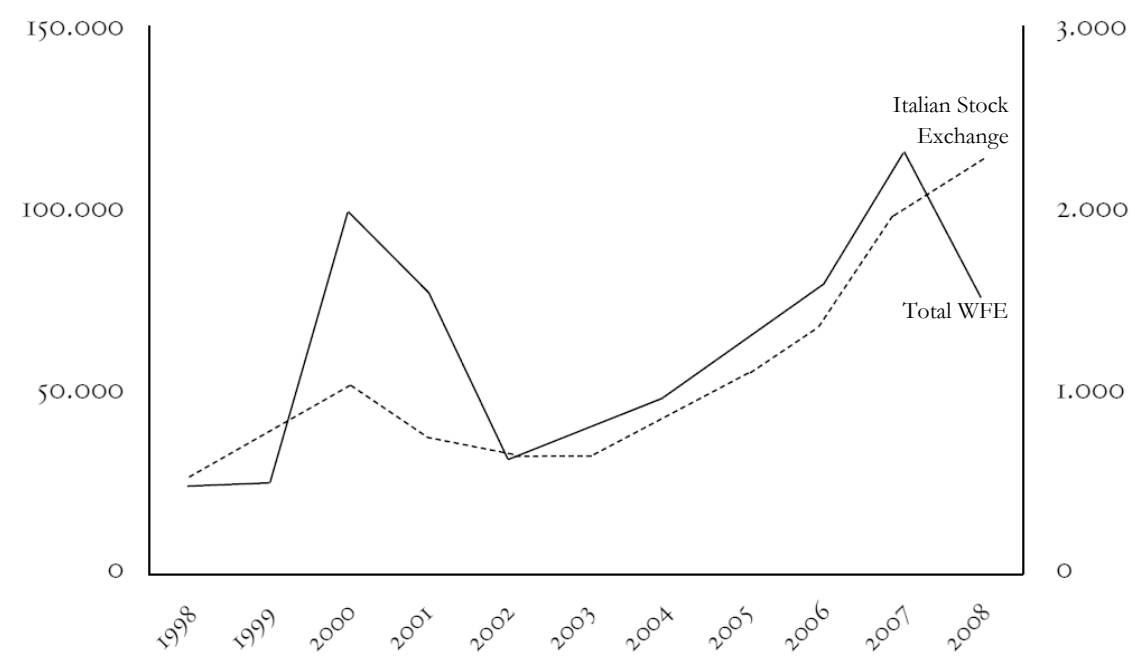

Source: World Federation of Exchanges.

In figure I, we show that the total value of stock tradesincreased by a factor of three in only ten years (it quadrupled in Italy). The total value of 
financial products reached, in 2007 , the $359 \%$ value of the world's gross product, with an average increase of $9 \%$ per year since 1990. While these numbers seem to speak for themselves, there are different ways to interpret (and measure) the general financialization of the economy. One could distinguish at least five somewhat different (although not necessarily mutually exclusive) perspectives, focusing on different explanations, issues or disciplinary interests.

A first, widespread interpretation proposes the idea of financialization as the product of a speculation bubble. According to this view, a sort of financial branch of the economy developed autonomously from the "real" economy, guided by somewhat "irrational" or non-rational evaluations and expectations (Beunza, Starck, 20I0; Godechot, 2000). As the goal of these actors is not the efficiency of the companies they invest in, but their personal wealth, behaviors based on self-fulfilling prophecies seem to emerge. The value of financial products increases not because of what happens in the "real economy", but because of expectations about their own increase. That is how the enormous power of major investors is explained. They are able to "make" the market (to generate huge financial products' supply and demand flows) and, by consequence, they control such expectations. Speculation bubbles are usually inflated (and/or deflated) by contingent situations (i.e., the introduction of a new technology), but their fundamental logic is related to social and psychological phenomena that are generated within the financial world, a very different mechanism from the traditional market equilibrium and efficiency dogma.

A second interpretation sees financialization as a systemic "answer" to declining industrial profits. According to this view, a shift towards a financial accumulation of wealth happens every time a certain economic system declines, for example because of the competition from other economic systems. Thus, the shift towards financialization represents a way to procrastinate the crisis. In this view, the most recent financialization process should be interpreted as a reaction to the decline of the American economy, started at the end of the 1970's under the pressure of new emergent economies, such as Japan and Germany (Arrighi, 1994, 2007). Even Marxist interpretations are somewhat similar to these lines, even though the decline of profits is viewed not as the outcome of increased competition, but as the consequence of increased monopolies. 
A third point of view is somewhat similar to the previous one, but it emphasizes the role played by the States, since the 70's, in determining the current financialization wave. Krippner (2005, 20II), in particular, described the significant role played by US policies in the last 40 years, in terms of deregulation of financial markets and other related policies which created a sort of financialization "spiral".

A fourth stream of studies sees financialization as the outcome of the domination of a new transnational capitalistic class. According to this view, the financial "boom" can be explained in terms of how these powerful groups accumulate wealth by using their power in the financial markets (Duménil, Lévy, 2006). This argument, clearly connected to a conflict-centered view of economic transformations, conceives the neo-liberist globalization of the economy as a "revolution from the top", that is, a significant shift of power in favor of large capitalists, generating increasing social inequalities (Harvey, 2005; Bryan, Rafferty, 2006; Radice, 20II, Gallino, 2012).

Finally, sociological studies focused their attention on the symbolic and cultural dimension of the financialization process and, more generally, of the neo-liberist culture (Bourdieu 2000; Thrift, 2005). These studies analyze the issue of the "embeddedness" of financial accumulation through the observation of the mechanisms by which the idea that the main "object" of the economic activity is not the production of goods and services, but the production of money, became legitimized and spread widely in societies (Davis, 2009).

Overall, while there are a number of different explanations and different points of interest by various disciplines, this large scale financialization process seems to be considered by many authors as a major phenomenon deserving careful consideration, at all analytical levels. Indeed, one should ask whether the macro-level "financialization of the economy" (however interpreted) translates, at the micro level, into something that we might call the "financialization of enterprises". With this expression we mean, in general terms, the tendency of enterprises (even non-financial enterprises) to increasingly rely on accumulation strategies based on financial means. More specifically, there are at least three different modalities through which such transition towards a financial accumulation takes place. 
The first modality is the use of cash flow, generated by productive and commercial activities, for financial investments - for instance, investments in financial derivatives, re-purchase of own stocks and financing of mergers and acquisitions (Milberg, 2008). According to Lazonick (20I0) in the period between 1997 and 2009, 438 companies of the SErP 500, listed in 1997, spent 2.7 trillion dollars for re-purchasing own stocks, on average 6.4 billion dollars each, and distributed about 2 trillion dollars in dividends, on average 4.6 billion each. Thus, we observe a large subtraction of resources from the industrial realm in order to access financial investments with relatively high profitability.

The second modality is the development of financial activities in parallel with industrial ones. In this case there is no clear separation between the financial and the industrial activities, like in the first case. Here, the financial activity is a sort of "child" branch of the main industrial activity. A typical example can be found in those companies that provide financial services to their own customers who want to buy their products. This happened for quite a long time in industries such as the automotive and others. However, while in the past these financial activities were mere instruments for the industrial strategy of the company, today the relationship is somewhat inverted. Profitability is higher in financial services, so that industrial activity becomes instrumental to the financial strategy. Goods are produced in order to sell financial services, not the other way around. According to Blackburn (2006), in 2003 General Electric Capital generated $42 \%$ of all GE Group profits. In the same year, General Motors and Ford generated the vast majority of their profits from leasing services. In 2004, General Motors Acceptance Corporation earned 2.9 billion dollars, which is about $80 \%$ of all General Motors Group earnings. The whole idea of "core business" is shifted towards the financial services and products, even for traditional industrial companies.

A third modality is the increasing focus of enterprises on the goal of shareholder value maximization. While some may argue that this orientation is inherent in the fundamental idea of "private company", in the last thirty years the focus on capital gains has become exasperated. Indeed, the top managers' compensation depends mostly on capital gains. The focus on shareholder value has dramatic consequences at many levels. The most visible effect is to shift the attention on the short or very short 
term returns. As Gallino stated, this means that the wide adoption of the principle according to which profits are identified not just as the difference between revenues and costs but also - preferably - as the difference between the shares' value at the time $t_{2}$ and the value at the time $t_{1}$, where the difference between $t_{2}$ and $t_{I}$ can be as short as just a few days (Gallino, 2005). A corollary to this approach is the priority given to shareholders' interests over any other stakeholders' interests. The idea of the company as a social institution, embedded in a social context, is thus dissolved.

It should be noticed that the financialization of enterprises is not a recent phenomenon. Fligstein (1990) showed that at least two different "eras" of enterprises' financialization can be identified. The first one, in which the company is conceived as a portfolio of investments, was introduced by a new generation of financially trained managers. The company is not seen as a unitary production system, but as a set of product lines generating cash flow which can be de-composed and re-composed in any way in order to get the best possible return on investments. This concept maintained its prevalence until the 8o's and, in some countries (in Italy, for example) at least until the early 9o's. In the second "era" of financialization, starting in the 8o's in the US and then spread in other countries, the idea of shareholder value maximization was asserted as the new dogma, a new way to conceive and control the business enterprise.

However, while the essential aspects of enterprises' financialization are quite clear from a qualitative point of view, it is surprisingly difficult to find any aggregate data about it. According to Palley (2007), the total profit of financial companies was $25.7 \%$ of the profits of non-financial companies in the I970s, but the ratio increased to $49.7 \%$ in the year 2000 . In addition, according to OECD data, the added value of the financial sector as a percentage of the added value of all sectors increased rapidly and steadily between 1970 and 2007 in most OECD countries. In the US, the increase went from about $18 \%$ to well over 32\%. In Germany, it went from about $13 \%$ to about $28 \%$. Similar trends can be observed in Spain, Italy and France. These data clearly show the shift in the production of wealth from the industrial sector to the financial sector. However, the most interesting data is provided by Kippner (20II), showing the dramatic increase of financial income vs. industrial income in non-financial companies (Figure 2). This chart clearly illustrates the dramatic financialization process of nonfinancial companies. 
Figure 2. Percentage of financial profits over total cash flow in non-financial companies in the US

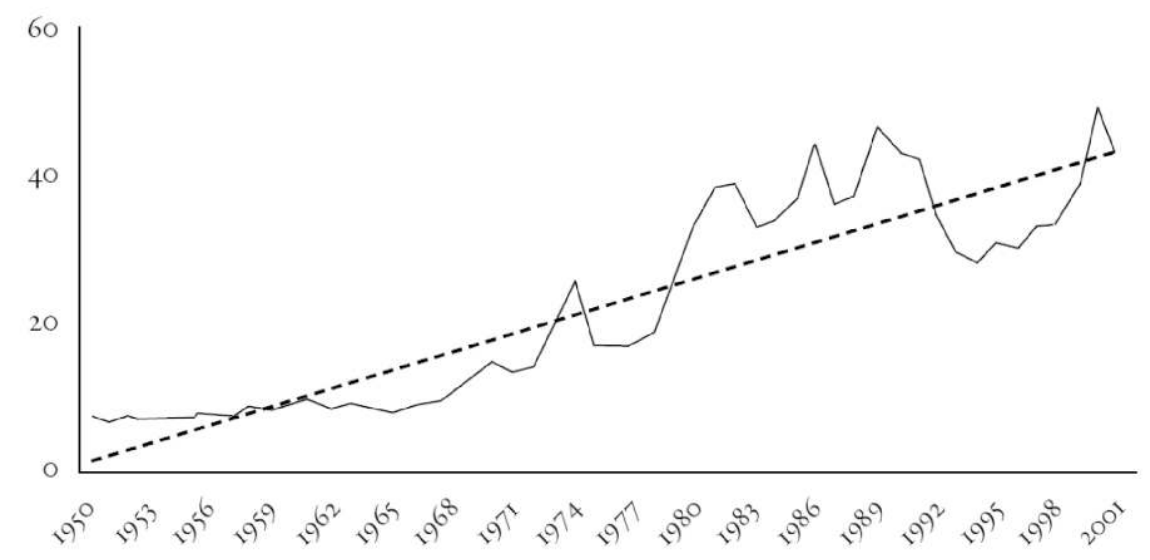

Source: Krippner (20II, page?).

Thus, it seems safe to argue that the qualitative and quantitative relevance of the financialization process - both as a macro-level and a micro-level phenomenon - can be hardly neglected. Indeed, a large literature offered many theoretical accounts, from various disciplines and points of view. In this paragraph we could only scratch the surface of the several debates about the various topics related to the financialization theme. However, the current literature does not seem to explore in sufficient detail a very simple but important question, that is, whether financialization is having any role in shaping the organizational choices of companies. There are some exceptions, of course (Lazonick, 0'Sullivan, 2000) but there seems to be a clear need for more empirical research specifically guided by organizational analytical categories. As we already argued previously, available explanations of the Post-fordist paradigm (both apologetic and critical ones) seem to focus on concepts and analysis mostly based on an "industrial" logic. Instead, we need to understand if and how the so called "Postfordist" way of conceiving, managing and organizing companies can be at least partially explained in terms of the current financialization process. In the next paragraphs we propose, through the support of empirical data, that considering a context of widespread financialization (at all levels) greatly helps to explain why and how enterprises are managed and organized as they are today. 


\section{THE ANALYTICAL FRAMEWORK}

A few authors identified some of the main strategic and organizational features that characterize financially-oriented companies (Lazonick, 0'Sullivan, 2000). The most important ones are: i) the tendency to abandon long-term programs and plans; ii) the use of financial mechanisms in order to increase the shares' value; iii) the tendency to replace technical managers with managers trained to have a financial orientation; iv) the use of large sums of money to cover agency costs; v) the widespread use of mergers and acquisitions; vi) the reduction of profits coming from production and sales of goods and services; vii) the reduction of labor costs and the substitution of fixed costs with variable costs. While these findings are generally accurate, a more detailed and complete analysis of the relationships connecting these and other strategic and organizational characteristics with the financialization process seems to be necessary. In order to explore such connections in more depth, we based our empirical investigation on an analytical framework proposed by Maggi (200I, 2003). The author identifies three analytical levels (from micro to macro): the work situation (work organization and other coordination and control arrangements in the workplace), the general configuration of the company (overall formal structure, general organizational and human resource policies) and the external relations with other organizations (outsourcing policies and other inter-organizational arrangements).

We start from the "meso" (intermediate) level. Contrary to what is almost unanimously claimed by the mainstream literature on Post-fordism, it seems unlikely that the financialization of enterprises allows decentralized formal structures. On the contrary, a focus on short-term, financial results requires a very strong emphasis on centralization of competences and, even more, of decision making prerogatives. As we will see in the next sections, the CEO (or, even better, the CFO) of a centralized company is able to control quickly and directly all the relevant operational "leverages" in order to adjust the financial results of the company and, by consequence, to meet the short term expectations of the financial markets. The short term orientation requires the ability to act quickly and precisely towards certain kinds of outcomes. Thus, a high degree of centralization of formal configurations is what we expect to find in financially oriented companies. Another relevant aspect is the tendency to "restructure" 
and "reengineer" the organization - practices which literally boomed in the 8o's and 9o's, but still continue today, although with different labels ("downsizing" or, more euphemistically, "rightsizing"). The practices to decrease the size of operations, to reduce labor, to focus on the "core business" - usually justified in terms of rationalization of production respond to precise financial needs. When the company is managed as a portfolio of activities, the goal is to maintain only those activities that are best suited to generate the highest return on equity, as demanded by the financial markets.

Thus, overall, at this analytical level we expect to observe a strong tendency to centralize formal structures, to downsize operations and to increase the relevance of financially trained managers.

At the "micro" level (the work situation) a company conceived as a financial mechanism, that is, a nexus of contracts, according the terminology of the agency theory (Jensen, Meckling, 1976) will show a tendency to destructure the organic relationship between workers and managers. The volatility of the financial capital is accompanied by the precariousness of work - that is, the continuous adjustment of "human resources" to the financial needs of the company. The goal is to reduce labor costs and to transform fixed costs into variable costs. The Post-fordist rhetoric emphasizes the relevance of workers' initiative and the intrinsic "value" of people. Indeed, their initiative and knowledge is requested (within the limits of allowed discretion), but it is immediately acquired as a system's property, it is de-personalized and generalized. In other words, the goal is to make every person as replaceable as possible. In this context, the precariousness of work contracts is the key to this new production modality. The workers (both at the operational and at the middle management level) are treated as internal "customers". As mere "contractors" with the company, without any real organic "citizenship", they are the target of significant internal communication (and training) initiatives aimed at maintaining a decent level of motivation in order to get an adequate work performance. Even the higher level managers are under the double pressure towards commitment and competence on the one hand, and responsiveness to the financial imperatives on the other hand. A sort of "schizophrenic" condition (as we will see later in more detail) in which managers, while 
appearing more powerful than ever, instead seem to suffer from a reduction of actual autonomy.

Thus, overall, at the work situation level we expect to see a general effort to increase the workers' condition as "replaceable parts", to increase motivation and commitment through pervasive communication and training policies, to reduce the autonomy of middle and even higher level managers,to reduce labor costs and to transform fixed labor costs into variable costs.

At the third level - the inter-organizational one - the outsourcing practices are usually explained in terms of transaction cost economics (Williamson, 1986). In managerial terms, this is described as the attempt to emphasize and focus on firms' "distinctive" capabilities and competencies. This kind of explanation, though, is not always accurate. Indeed, one might argue that very often it is hard to justify all the inefficiencies (even in terms of coordination and integration difficulties) that these operations actually imply. Instead, the big wave of outsourcing and externalization operations of the I99os seems to be better explained by financial motives. These are operations that provide great financial advantages in the short term, as they generate large amounts of cash, which are then reinvested in financial operations. They are also remunerative in terms of shareholder value, as they are very appreciated by the financial markets. It should also be added that externalization and outsourcing operations, with their extended dynamics of inter-organizational dependencies and control, tend to bring to the world of small and medium enterprises the same financial logic to which the large enterprises are exposed. Thus, the whole value chain becomes dependent on the same financially oriented "rules" as they penetrate the boundaries of SMEs, not just in cultural terms but also in operational terms.

In the next paragraphs, we will illustrate our empirical evidence consisting of two different sets of data. In the first one, we analyzed a significant number of case studies from a variety of multinational enterprises. In the second one, we will report in-depth qualitative interviews with very high level managers. 


\section{DATA AND METHODOLOGY}

We based the first part of our empirical work on text materials generated by a well known Italian Research Program called "Officina di Organizzazione" (Organizational Workshop) ${ }^{2}$. The Program produced so far about 150 case studies concerning many large multinational companies. Overall, more than 70 different companies participated to the Program, many of them for several years - in fact, some of them participated for I5 years or more. The case studies concern a variety of areas: formal structural changes, outsourcing initiatives, human resource management practices, mergers and acquisitions, work organization, technological changes, etc. All cases have a specific organizational and human resource management focus. Each case study is the outcome of a full day of work where a manager (usually a very high level manager in the organizational or human resource area of the company) presents to his peers (other managers, with similar positions, from other companies) a case of organizational transformation in his company, normally a very significant project that he managed personally. The presentations are very detailed, and they last three to four hours. After that, a session of questions and answers is carried out, followed by an open discussion session where all participants analyze, criticize and discuss the case study presented by the manager of the company. Thus, the whole day is focused on one case only. This ensures a high level of focus and detail. Researchers do not actively participate in the presentations or discussions - their only role is to facilitate and coordinate the whole process. Everything is tape-recorded and reports are then written by researchers who attended the event. No information is published in any way without the companies' consent. A few aspects make this data source particularly interesting and, in many ways, unique.

First, the topic of each case study is chosen by the company itself. The company's manager chooses what project(s) or initiative(s) to talk about, depending on what he/she thinks is relevant in his company at that moment. There is no external influence or bias on the topic selection or on the way managers present their cases. They enjoy complete freedom. Needless to say, discussions are as free and as open as the presentations.

2 For details about the Research Program, please see www.taoprograms.org/ 
Second, all the researchers who prepare the reports put a lot of care and attention in order to make sure that the reports are as faithful as possible to the narrative of the managers. All key elements - like the language, the examples, the topics and sub-topics, the overall narrative - are all left untouched by the researchers, who are mere "collectors" of textual evidence from the companies' managers. Reports are usually 20 to 30 pages long.

Third, it is worth noting that managers present to (and discuss with) an audience of peers. The events are not public. They strictly involve only a close circle of managers who end up knowing each other quite well and are willing to participate (often, for many years in a row) in order to openly discuss and compare what is happening in their respective companies. Thus, presentations and discussions are usually quite transparent and frank.

All case studies are very homogeneous in all the above mentioned aspects.

In this paper we focus on all case studies available (57) from 1995 to 2008. The reason is that in 1995 one author of this paper started being involved in the Research Program, so he could be present in all the events. We also decided not to include more recent cases in order to avoid the possibility that the current economic crisis would bias the results. About $18 \%$ out of the 57 cases concern enterprises of the financial sector (banks, insurance companies, etc), 33\% concern manufacturing companies (automotive, chemical, energy, etc.), 30\% concern service firms (mostly large retailers), and $19 \%$ concern firms from the technology industry (computing, software, telecommunications, etc.). All companies are very large multinational firms, with headquarters in a variety of western countries. It is worthwhile noticing that the inclusion of financial companies (banks, insurance companies, etc.) is justified by the observation that the organizational consequences of "financialization" can also be observed in this sector. Just like any other sector, financial companies may be pushed towards short-termism, centralization, marginalization of labor, etc., by their increasing dependence on financial markets. One can distinguish between an "industrial" logic and a "financial" logic even in the financial sector. 
In this paper we present the results obtained by using a thematic analysis approach. After several rounds of reading and evaluating all the reports, we defined a structure of "thematic codes". Codes were defined qualitatively. Overall, we defined 53 codes divided in 7 different groups. Each group represents a general area of organizational themes. Each code identifies a specific theme.

The Groups are the following: General goals of the company, Macro-level organizational transformations, Micro-level organizational transformations, Human Resource Management policies and initiatives, ICT-related organizational transformations, changes about Suppliers and other External Actors relations, Organizational Culture. While we recognize that the choice of codes is purely arbitrary, it is worth considering that the final coding structure was chosen after several rounds of careful, crossexamination of all cases, in order to define codes that actually reflected the content of the reports. In other words, we tried to decrease, as much as possible, the influence of the researchers' perspective and interests in defining the coding structure. Of course, such subjective influence cannot be completely eradicated, so the outcome still has to be interpreted as somewhat arbitrary.

Each report was then "coded". More precisely, a number of excerpts (text segments) of each report were identified and associated to one or more codes depending on their meaning and content. Once again, the coding process is purely arbitrary as well. However, we performed a practice of cross-coding in order to consider only the excerpts in which all authors agreed on the coding. Overall, we identified 790 text segments for the 57 cases (on average, almost i4 excerpts per case study). We did not code any accessory elements to the case studies, but we coded only information that specifically referred to the actual organizational transformation discussed in the report (for example, no reference to past changes or other companies was coded). One brief example of a codified segment is the following:

"The project team decided to develop a unified, centralized system (a Single Global HR System), in order to achieve a shared management of data, and also in order to allow the headquarter to control what was happening in the periphery, and to standardize some of the most important work processes." 
This text segment was coded with the "Centralization" and the "Work Standardization" codes, because these are the key concepts conveyed by the segment, according to our interpretation.

While multiple coding for the same text segment was widely used, we tried to avoid multiple coding related to the same information - in other words, we tried to avoid to code different segments with the same code when they referred to same information. For example, the segment above was not coded with the "Unification of ICT systems" code (although it does imply that such process happened in the company) because in the same report there are other segments referring more specifically and extensively about the same event. Overall, a total of I23I codes have been applied - on average, about I. 5 codes per segment, and 2I.5 codes per case study. We used a software application called "Dedoose" for all the coding operations.

The goal of our analysis is an exploratory, descriptive one. We are not attempting to test any quantitative hypothesis. Our aim is to identify some general patterns of organizational change in large multinational companies in the last 15 years. We are not claiming in any way that the patterns that we identified have general validity. In order to understand what could be the extent of their significance it is necessary to clearly point out both the strength and limitations of our data and methodology.

As far as strengths are concerned, we believe that our set of case studies is quite unique in terms of number of companies, variety of industries, economic and cultural importance of the companies, level of detail, homogeneity in their construction and, most of all, faithfulness to what the managers freely choose to describe (content, language, emphasis, etc.). Thus, this data set provides an interesting opportunity to study what is happening in large companies starting from the narrative used by the managers themselves in order to explain, describe and rationalize their own work. It should also be mentioned that the Research Program that generated the data is solely concerned with organizational changes. In other words, no specific request whatsoever was ever made to the managers in order to make them talk about financial issues.

As far as limitations are concerned, 57 cases - while being a very high number for qualitative studies - is probably not high enough to allow a 
reliable quantitative approach to pattern-finding, although we are going to explore such possibility in future works. Also, the thematic analysis approach is sensitive to the researcher's own perspective and subjectivity. As we already stated above, while we tried to limit the "subjectivity" problem through cross-coding, the fact that most interpretive choices are arbitrary cannot be denied and should be carefully considered.

\section{ORGANIZATIONAL CHANGES AND FINANCIALIZATION OF ENTERPRISES: RESULTS AND INTERPRETATIONS}

The first, most basic question we would like to try to answer is the following: what are the themes appearing most often in organizational change processes of large multinational companies? In figure 3, the i2 codes (out of 53 total codes) appearing more frequently, and their percentage of appearances on the total number of code apps (I23I), are shown.

The most frequent code is "Efficiency", which was applied every time the managers stressed the idea of reducing costs. "Centralization" is the second most frequent code, applied every time the managers talked about centralizing their formal structures. These are significant percentages, if we consider that, out of 53 different codes, 3I obtained a percentage of appearance lower than $2 \%$, and 22 lower than $\mathrm{i} \%$ each. In other words, some themes are five or six times more frequent than others. It is also useful to measure the "diffusion" of each theme (that is, in how many cases each code appears at least once). "Efficiency" appeared at least once in $72 \%$ of case studies. "Centralization" appeared in $53 \%$ of cases. Also the theme "Performance" (which was applied every time the manager referred to financial results) is one the highest codes in terms of diffusion (40\% of cases). The wide diffusion of codes such as "Efficiency" and "Performance" is particularly striking if we consider that all case studies were focused on organizational issues or human resource management issues (not on financial or accounting issues), and that the managers involved all came from the organizational or human resources areas. 
Figure 3. Overall frequencies of codes

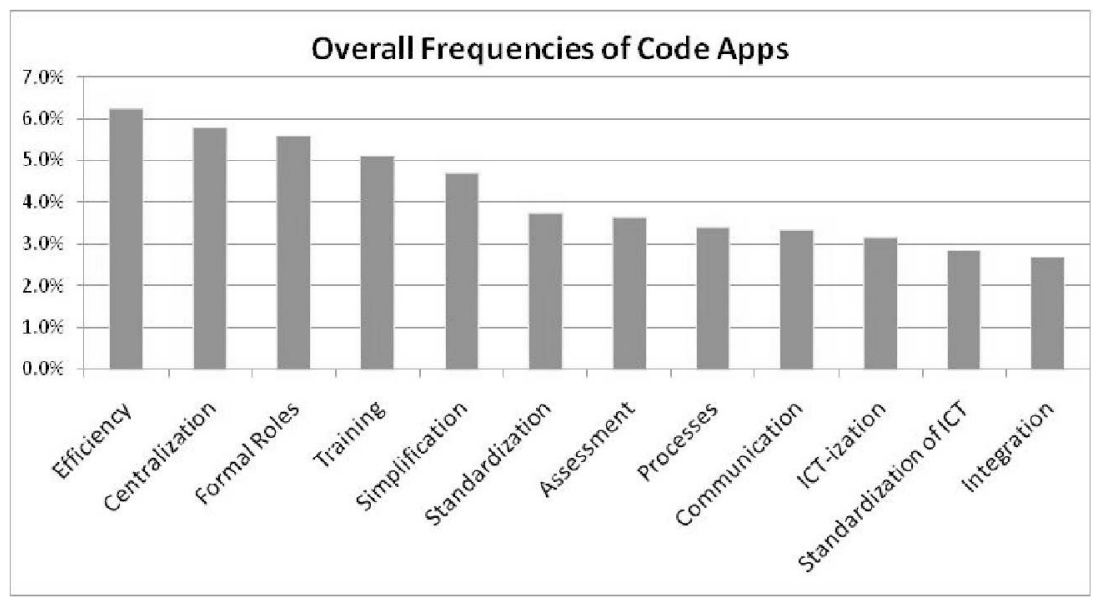

It is also interesting to notice the relevance of "Centralization". This can be associated with another very frequent code, "Simplification" (which was applied every time the managers talked about organizational arrangements aimed at simplifying or reducing the complexity of their formal structures). Such code is the fifth (out of 53 ) in terms of overall frequency, and fourth in terms of diffusion (it appears at least once in $54 \%$ of all cases). If we consider the intermediate analytical level that we introduced in the previous paragraph, these two themes are by far the most relevant in our analysis. The centralization - simplification "duo" portrays a situation in which enterprises are pushing towards highly centralized structures, in which control is concentrated in the hands of just a few top level managers, where simplification allows to both reduce organizational costs and to make the "command and control" approach more effective as the whole company becomes more responsive to top level decisions.

We can also compare two opposite themes, "Centralization and Decentralization". In figure 4, we reported the trends that we found in our analysis. It is worth remembering that in the current mainstream rhetoric about Post-fordism, decentralization is depicted as the most important and distinctive features of these supposedly "new" enterprises.

As figure 4 shows, the "Decentralization" theme does not attract manager's attention at all, while "Centralization" not only is one of the most debated 
topics, but it seems to be increasingly popular among managers, in the last few years. It is worth repeating that our data do not have any statistical significance, and these charts are just a convenient way to represent evidence from a large number of qualitative case studies. Nonetheless, it seems that our evidence shows a certain consistency to what is possible to hypothesize about how financialization creates new constraints for the organizational choices of firms. The same can be shown if we look at themes that concern the "micro" level of analysis. The code called "Empowerment" (which was applied every time the managers talked about initiatives aimed at increasing the autonomy and the responsibility of workers and the enrichment and enlargement of jobs) only appears in II \% of cases, and its absolute frequency is only I.I\%. Also, if we look at the time series, it seems that the interest for empowerment initiatives is rapidly decreasing in the last few years.

Figure 4. Centralization vs. Decentralization time series

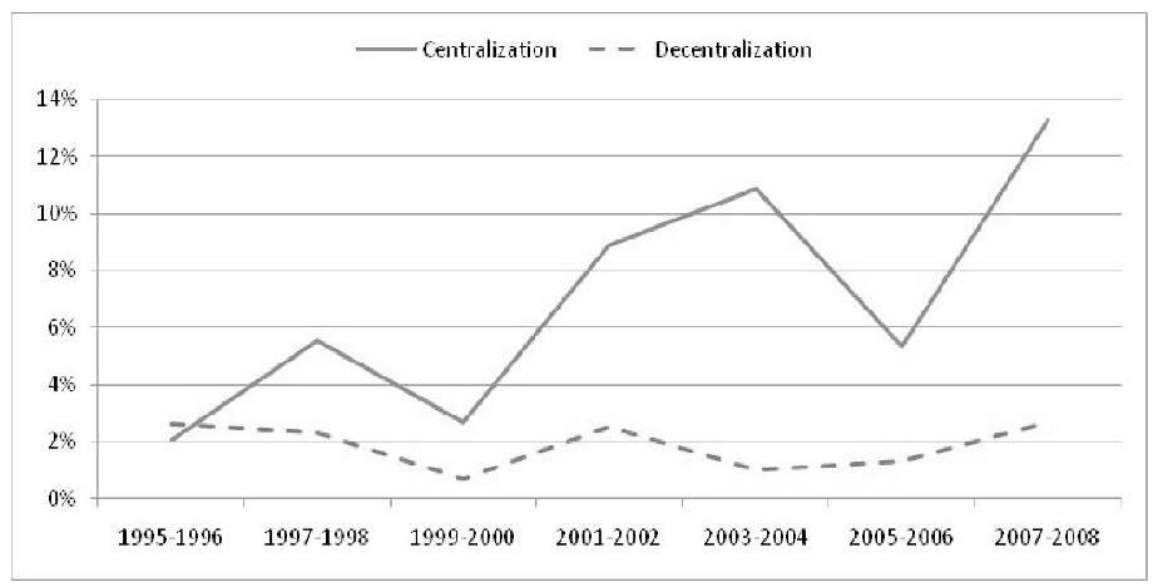

We also tried to categorize our sample of case studies by general type of industry or sector: financial sector (banks, insurance companies etc.), services sector (mostly large retailers), high-tech sector (telecommunication, electronics, computers etc.), and other manufacturing sectors (automobiles and other traditional industries). In table 5 we show the 4 most frequent codes for each sector. 
Table 5. The four most frequent codes for each macro-sector

\begin{tabular}{|cc|cc|cc|cc|}
\hline FINANCIAL & $\%$ & MANUFACT. & $\%$ & SERVICES & $\%$ & HI-TECH & $\%$ \\
\hline Training & $9.1 \%$ & Centralization & $6.6 \%$ & Efficiency & $9.9 \%$ & Roles & $7.4 \%$ \\
\hline ICT Unification & $7.5 \%$ & Training & $5.6 \%$ & Simplification & $7.0 \%$ & Assessment & $7.4 \%$ \\
\hline Assessment & $6.4 \%$ & Simplification & $5.2 \%$ & Roles & $6.1 \%$ & Centralization & $5.9 \%$ \\
\hline Standardization & $5.9 \%$ & Efficiency & $5.0 \%$ & Centralization & $5.8 \%$ & Efficiency & $4.4 \%$ \\
\hline
\end{tabular}

In the financial and the manufacturing sectors, training and education have a prominent role. This is not the case in the services and hi-tech sectors. At first sight, this could seem somewhat surprising, as it is usually believed that in high-tech and services companies human capital is mostly relevant. However, the contradiction is solved if we look at the possible goals of these training initiatives.

In the financial sector, besides the focus on training, the emphasis is on themes such us the integration and unification of information systems, on the assessment of people and work standardization. This is very consistent with what is clearly happening in many financial enterprises: the organizational arrangements are more and more dependent on technology-driven coordination and control mechanisms, and on work standardization aimed at accommodating the new computerized procedures. A high level manager of a major bank participating to our research program effectively summarized this idea in the following way: "In our industry, the organization is the information system". Thus, training and education policies, within this kind of context,clearly are not aimed at emphasizing the value of people's competencies and skills, but at converting and adapting their behavior to the requirements of the technological backbone of the company. It is a matter of people homologation rather than people development.

In the manufacturing sector the relevance of training should also be interpreted in relation to the centralization and cultural homologation tendency. As we can see from the table, in this sector the emphasis on centralization is particularly high. However, centralization is probably not enough to ensure a high level of compliance. In order to maximize the need to control, formal means are not sufficient, and informal means (such as 
training can be) are necessary as well. Indeed, it is interesting to notice that the code "Cultural Homogeneity" (which was applied every time the managers talked about initiatives related to internal communication or other similar actions aimed at improving the homogeneity of behaviors) is one with the most rapidly increasing frequency in the last few years. Thus, while centralization (formal control) is still at the top of managers' priorities, informal control is becoming more and more relevant.

The results concerning the high-tech sector may seem the most surprising ones. Again, centralization and efficiency play a major role, while the mainstream ideas about these sectors is one where themes like teamwork, innovation, decentralization, autonomy and human capital are supposed to be the most important ones. Instead, it seems that the managerial interest is mostly focused, even in this sector, in aspects such as efficiency rather than innovation, centralization rather than decentralization, formal role definitions and formal assessment rather than autonomy and people development. This is not to say that innovation, knowledge and human capital are not important in high-tech sector. However, it seems reasonable to hypothesize that the increasing pressure from financial markets is pushing even these companies to change their organizational and human resources practices in order to accommodate for a much higher attention to the short term outcomes and financial results.

\section{THE POINT OF VIEW OF MANAGERS}

Nothing is more telling than the vivid stories and points of view of the real protagonists. For our research, we decided to conduct in-depth interviews with some senior top-level managers (in the organizational and human resources areas) with a long experience in major multinational enterprises, in various sectors. Unfortunately, we cannot report the full interviews in this paper for lack of space, but the excerpts provided here represent very well their points of view ${ }^{3}$. Somewhat surprisingly, we found that all managers that we interviewed agreed with the general idea that financialization is a very influential phenomenon, even for decisions concerning

3 An extended report and commentary about these interviews can be found in Salento and Masino (2013). 
the organizational choices and personnel management. Indeed, we found, in more than one occasions, that the managers quite sharply criticize how financialization is changing the "face" of current organizations and management as a "profession" as well.

The first manager (manager A) was a senior, top level organization manager who spent his entire career in a major multinational oil company. He retired just a few years ago. The second manager (manager $\mathrm{B}$ ) is a senior, top level, human resource manager who, in the last 20 years, has had several experiences in a variety of multinational companies of different industries (automotive, chemical-pharmaceutical, mining). The third manager (manager $\mathrm{C}$ ) was a senior organization manager in a very high level position of a automotive multinational company. He also retired just a few years ago. The fourth witness is a senior consultant (consultant D) who worked for several decades with a large number of major companies in the field of organizational change, work organization and human resources.

\subsection{At the "meso" level: changes in general organizational structures and logic}

The first issue we want to tackle with our interviewees is the following: does it make any sense to talk about an emerging change in the fundamental orientation of the organizational and strategic choices? Is it possible to identify a shift in the overall logic, from an industrial to a financial one? Our witnesses have no doubt about it. Let us start with manager A, talking about his experience in a major multinational oil company which, in the mid gos, was listed on the stock market. This was the beginning of significant changes in the company: "The CEO realized that our numbers were worsened by some sectors. Our debts were heavy, the cash flow was low. We decided to create a central unit that had to manage the outsourcing. This worked out well, as it allowed to reduce debts, increase the cash flow and focus on the core business [...] this reduction of the industrial apparatus responded to the need a sort of "organizational cleaning" and strategic positioning, in order to recuperate a financial situation that would allow us to be listed in the stock exchange" (Manager A).

From an organizational point of view, the most significant changes happened during the ten years after the initial listing: "Everything changed. Beforehand, in this company [...] there was a strong sense of identity, generations of 
people that worked to charismatic manager who really represented so much for everybody. Our "flag" was our technical excellence, that was the shared value [...] This emphasis changed. The shares' increase in value was very much appreciated by the management, as part of our compensation depended on that [...] We used to say in our company: how it is possible that we have worse financial indicators than our competitors - for example, the earnings per share indicator? We need to be aligned to our competitors about these and other elements that determine the stock price. We need to cut costs. Others did it through mergers and acquisitions, we need to do it through internal growth and synergies. This was the strong mandate of the CEO in those years."

In the last 5 years, even more significant things happened: "Since 2005, a financial approach has become more and more relevant. There are many examples. The choice of high level people is one of them. A relatively young man coming from the financial sector, from another company, was placed in a very high level position with industrial responsibilities. This, just a few years before, was absolutely unthinkable. Also, the strategic planning approach was dismantled. The long term guidance of the company was weakened, and a CFO (Chief Financial Officer) role was established for the first time. The CFO takes on administrative, financial, insurance, accounting and $M E A$ responsibilities. The strategic plan is no longer defined by the specialized unit, but by the CFO himself. The CFO becomes the key governance role of the company, and his background is a financial one."

Even Manager C tells a similar story from his experience in a major automotive company: "Financial control become more and more important, very rich of indicators and tools, and it is more and more integrated with accounting. The financial "reading" overlaps with the industrial one. Until the 1970s we didn't have a CFO, and then gradually, once we created a financial direction, the unit became closer and closer to the CEO, and the same goes for the ICT unit [...] The CFO becomes very important: he has to find the money, to control the use of the invested capital by product lines, country, division, business. Indeed, today we talk about CFOO (Chief Financial Operating Officer), a real business manager, someone who has to put the money where there are more returns. This is my experience" (Manager $\mathrm{C}$ ).

Manager B is even more explicit about his experience in the chemicalpharmaceutical industry. He focuses on the short-term orientation, which becomes a sort of obsession: "The problem is that investors have no brains of their own, even if they don't invest really just to sell, nonetheless they are deeply influenced by the investment groups. The quarterly report is the bible, quarter after quarter [...]. 
In those times of the year when you have the short-term obsession, you have to do anything to save the short term results, in order to save your ability to manage the long term you need to show short-term results, you are caught in this schizophrenic dilemma. Even those companies that claim to be more "strategic", they are not. This is the reality of most listed companies. It's a balancing act between the long and the short term [...]. First we talk about vision, human resource development etc., and the next month we observe "primordial" reactions [...]. I have to fire people on which I invested just a month before for their growth and development [...]. This inconsistency creates tensions between people. And when you have strong tensions, you abandon long term projects. If you have bad results for two quarters you don't care about the "vision", you manage the long term with short term decisions, and that is irrational [...]. If the shareholder asks a lot of dividends, this influences a lot the HR manager and his choices. Also, the short term shareholder may be interested in selling, not just dividends" (Manager B).

Another interesting aspect concerns the managerial actions and decision as communication acts towards the financial markets, in order to reassure them, to show "activism" and competence, to show that the management is "in control". Again, manager B: "We sold businesses just to show that we were reacting. We bought businesses just because we thought that the stock market might like it. Management choices became a way to communicate to the financial community - for example, to save the quarter. We had to show investors that we were doing something, that we were cutting costs." Here is Manager A, on the same topic: "The nee CEO gave a lesson about shares' value, and he stressed that it depends $50 \%$ on the actual results, and $50 \%$ on how we communicate those results. Hence, the great relevance given to external communication, many people were hired in this area, a complete managerial renewal, at many levels."

Organizational choices are strictly related to all these issues. And centralization is by far the most frequent one. Here is what Manager B has to say about it: "Centralization allows to "pilot" the company just like it was a game, like with a joystick. If I want to steer the management according to what the Stock Market is asking, I need a centralized approach, decentralization does not allow me to do it. Centralization is directly connected to what I call "CEOization", because CEOs must appear on the market not as someone who just defines general directives, but as someone who acts and does things, someone who is able to tightly control the company [...]. In multinational companies, centralization is a very widespread, constant tendency, even if there's always someone claiming that we need to decentralize, but companies 
usually centralize. In the pharmaceutical company where I worked for so many years, this tendency was extremely obvious. More or less the same thing happens here, in the company where I work today (in the mining industry). Today I can do from the center things that 3 years ago were unthinkable, for example, I can decide where to place and move people even in very remote units, thanks to a sophisticated, centralized system of talent management and also thanks to new technologies. Technology helps because everything becomes remote, it gives me all the data I need. Everything is easier."

Thus, centralization is useful for two reasons: i) it ensures that the company is very responsive, in a quick and direct way, to the top managers' decisions which, in turn, depend on the short-term expectations of the financial market; ii) it represents the best way to communicate to the financial market that the top managers are able to control the company without hesitations or compromises. In a way, centralization represents a sort of organizational "insurance" for the financial markets that the company is and will be managed according to their short-term interests. Manager A also puts a lot of emphasis on centralization: "Since the beginning of the 90's, the pursue of efficiency happened through a number of centralization projects of activities and service that, beforehand, were performed within each business unit. The first project concerned the financial activities, that were completely centralized. Then a project about RED and the unification of the technology development that is, a number of assessment activities were centralized, and a committee for the coordination of common resources and technological development themes was created. Another project concerned the centralization of the information technology management. Human resources management was also mostly centralized, as well all the insurance area, which for the company is very important. Recently the remaining administrative prerogatives that were left in the business division have been centralized as well ..thus, overall, in the last 15 years, we had this strong focus on costs reduction through actions that were guided by the idea of unification and integration - the keyword was centralization. This is my experience: efficiency and centralization."

\subsection{At the "micro" level: changes in the workplace}

Financialization influences micro-organizational choices in many ways. First and foremost, the obsession for cost reductions strongly pushes towards dramatic decreases of labor costs. Here is manager A: "In the last 15 years my company reduced dramatically the overall number of employees, about $30 \%$, but even $50 \%$ or more in certain countries." The "downsizing" policies are 
widespread, often connected to operations such as mergers and acquisitions, process reengineering, changes in personnel policies and so forth. Consultant D worked for many years with major companies in the areas of training $\varepsilon$ education and work organization. He emphasizes a decreasing attention and interest by managers to workers' knowledge and competencies: "Years ago managers were aware of this "unknown area" between organization and work, where the workers' knowledge was absolutely crucial, they knew it was crucial and they wanted to understand it [...]. A personnel manager used to travel, used to go were the problems were, we talked about the problems in the workplace. Today managers are very far from the problems. They don't care about the idea of understanding the workplace. They care about the external world, how to bring in resources. They see the company as global investment [...]. They do ask us to do training to the workforce, but they don't really care about the analysis, all they want is results. They assume that everything is understood already, so they ask for results, but this is not the way it works" (Consultant D).

In other words, the financialized company does not look at the workplace as a source of knowledge to improve processes or to achieve innovation. Instead, the company requires immediate results, and even training is conceived as the application of predetermined notions and models, based on the assumption that the "one best way" not only exists, but it is already well known. Again, Consultant D: "There is no recognition for understanding the specific training needs of the people. Today companies pay a certain educational agency, they go there and provide their courses without even considering the idea of analyzing the specific training needs. It's all pre-packaged. The context doesn't matter anymore." Also, on the way people are considered in the workplace: "Even the term 'human resources' is financialized, because people are 'resources', they are 'production factors', they can be replaced anytime. Once, we had 'experts' in the workplace, not resources" (Consultant D).

Education and training (personnel development) is de-materialized, it is just a cost, not an investment. It is not a learning process which depends heavily on the context, it is a predefined package of notions transmitted to the workers and aimed at homogenizing and controlling their behavior. Manager C is explicit about this: "Today the relationship with people is different. There are no more significant investments on people. The organization is very variable. We have teams and interfunctional units and relations, all mediated by the information system. The job of the personnel manager is to have a direct relationship with only 
a small part of the personnel, the 'talents'. They are the ones on which the company makes investments. And then you have the "mass" of people, which is smaller (because in the meanwhile I reduced the employees by a factor of four or five) but it still a mass. And the mass can be controlled through hierarchy. Thus, the relationship between the person and the company is de-materialized" (Manager C).

This tendency to a polarization between an "élite" of talents, and a mass of anonymous, replaceable workers is very interesting, and it well represents how a financialized company sees the personnel management problem. Investments on people do not disappear, but they are concentrated on a small selection of "talents". All others are just "resources" to be controlled and / or costs to be cut in order to improve the financial results.

\subsection{At the "macro" level: outsourcing and inter- organizational choices}

As we already argued, outsourcing initiatives are usually described as a way to rationalize industrial operations. However, financial goals can also be very relevant: transformation of fixed costs into variable costs, increase of liquidity to be invested in financial operations, and so forth. Manager $\mathrm{C}$ agrees on the possibility of different interpretations: "First, outsourcing can be a way to focus on the core business, or to reduce the internal complexity. But it also can be seen as way to generate cash and increase the shareholders value or to engage in financial operations. These are very different ways to see the issue, and they refer to the basic question: 'what kind of company are we thinking about'"? (Manager C). In some cases, Manager's $\mathrm{C}$ experience shows that these operations may go well beyond an industrial rationalization logic: "The assumption should be that I outsource activities to someone who has the competencies to do them well. In my experience, this was not always the case. The assessment of suppliers was not always very accurate and verified. In some cases, we outsource some 'pieces' to some suppliers who were not really able to deal with them" (Manager C). Also, there is the risk of losing competences. Not just because the knowledge about external activities cannot be accessed directly, but also because the need to directly and tightly control the suppliers (through information system, procedures, logistics or other informal means) may reduce their autonomy and their ability to experiment, learn and innovate. Manager $C$ agrees on this: "Absolutely, this is one of the main problems of the networked company [...]. 
Especially when there is a technological change, this is a real risk. When the technology is stable, this is not a major issue" (Manager $\mathrm{C}$ ).

Another issue concerns the development of financial services in parallel to the industrial activities, as we already described in previous paragraphs. The boundary between what is "core" and what is "non-core" becomes very blurry. Again, Manager C: "There are new logic, new tools. This can become a crucial issue for many companies. This is because if I have a cash problem, the market will not forgive you, the quarterly report becomes crucial [...]. For example, the financial services to the customers... you need to understand if this a service to the customer or a business in itself. In the company I worked for this is an old issue. When we had our won financial unit, we had infinite discussions [...] but at the Corporate level the financial unit was considered an autonomous business, so the Holding manages business units and financial units just like a portfolio of investments" (Manager C).

Thus, even at the macro-level, the financial orientation seems to be very influential in how the outsourcing initiatives are planned, how the relationships with the suppliers are managed and how the relation between industrial businesses and financial businesses define the "identity" itself of the company.

Overall, our interviews confirm, at least from the vantage point of view of our interviewees, a clear shift from a general industrial strategic logic to a financial one. This leads to short-termism, to organizational choices that seem to contradict the general industrial strategies, and to a decrease of the relevance of the strategic reasoning itself. It also leads to a general organizational picture that sharply contradicts the mainstream rhetoric about Post-fordist companies.

\section{CONCLUSION}

It is worth repeating that our empirical results cannot be generalized in any way. Very different stories and case studies may be certainly found, since in the world of organizations there are surely many "exceptions" to whatever the "rule" is. However, the relevance of the companies in our sample (all major multinational companies) as well as the level of responsibility and the length of experience of our interviewees (all top level 
managers with many decades of experience in major multinational companies) lead us to hypothesize that what we found about the dramatic relevance of financialization is not an unlikely coincidence. We strongly believe that in order to understand the current reality of enterprises, in managerial and organizational terms, it is necessary to rethink the way we conceptualize and explain the changes we are observing. Together with traditional explanations based on a logic of industrial rationalization, it is worth considering the enormous pressure coming from afinancialized economy. These changes do not necessarily lead to enterprises that are more "rational" in industrial terms, more "responsible" in social terms, more oriented towards long-term innovation and progress. On the contrary, it seems that a very different idea of rationality - indeed, a very different idea of "business firm", is not only emerging, but winning out. This is a system-level phenomenon, not just because it involves all major listed multinational companies on a global scale, but also because it may well involve a vast majority of the business world. Even those companies that - because of their smaller size, or because they are not listed - are not under the direct pressure of financial markets, are nonetheless likely to be pushed towards the same financial "logic" as a result of cultural influences or, even worse, of their organizational ties with listed companies. This is also a subject that should be better understood through the collaboration of scholars from different disciplines - economics, sociology, management, organization theory, and more. In a way, this paper also represents a "call" to a more cooperative effort to bring up the issues here discussed to the public discourse and to help the scientific community to imagine ways to avoid, or at least to reduce, the many dangers and negative consequences that seem to be inherent to an increasingly financialized economy.

\section{REFERENCES}

AGLIETTA M. (1979), A Theory of Capitalist Regulation: The US Experience, Verso, London. AGLIETTA M., REBÉRIOUX A. (2005), Corporate Governance Adrift, Cheltenham-Edward Elgar, Northampton.

AMIN A. (ed.) (1995), Post-Fordism: A Reader, Blackwell, Oxford.

ARRIGHI G. (1994), The Long Twentieth Century: Money, Power and the Origins of Our Times, Verso, New York. 
ARRIGHI G. (2007), Adam Smith in Beijing: Lineages of Twenty-First Century, Verso, New York (trad. it. Adam Smith a Pechino: genealogie del ventunesimo secolo, Feltrinelli, Milano, 2008).

BEUNZA D., STARK D. (20I0), “Models, Reflexivity, and Systemic Risk: A Critique of Behavioural Finance", Working Paper Social Science Research Network-SSRN.

BLACKBURN R. (2006), "Finance and the Fourth Dimension", New Left Review, 39, 2, pp. 39-70.

BOREHAM P. (1992), "The Myth of Post-Fordist Management: Work Organization and Employee Discretion in Seven Countries", Employee Relations, I4, 2, pp. 13-24.

BOYER R. (I990), Regulation Theory: A Critical Analysis, Columbia University Press, New York. BOYER R. (2OII), Les financiers détruiront-ils le capitalisme?, Economica, Paris.

BOURDIEU P. (2000), Les structures sociales de l'économie, Seuil, Paris.

BRYAN D., RAFFERTY M. (2006), Capitalism with Derivatives: A Political Economy of Financial Derivatives, Capital and Class, Palgrave Macmillan, London.

DAVIS G. F. (2009), Managed by the Markets: How Finance Re-Shaped America, Oxford University Press, Oxford.

DEMING W. E. (I986), Out of the Crisis, MIT Press, Cambridge (MA).

DUMÉNIL G., LÉVY D. (2006), “Costs and Benefits of Neoliberalism: A Class Analysis”, in Epstein (2006), pp. 17-45.

EPSTEIN G. (ed.) (2006), Financialization and the World Economy, Edward Elgar, Cheltenham-Northampton.

FLIGSTEIN N. (I990), The Transformation of Corporate Control, Harvard University Press, Cambridge (MA).

FREEMAN C. (ed.) (1984), Long Waves in the World Economy, Macmillan, London.

GALLINO L. (2005), L'impresa irresponsabile, Einaudi, Torino.

GALLINO L. (20II), Finanzcapitalismo. La civiltà del denaro in crisi, Einaudi, Torino.

GALLINO L. (2012), La lotta di classe dopo la lotta di classe, Laterza, Roma-Bari.

GODECHOT 0. (2000), " Le bazar de la rationalité. Vers une sociologie des formes concrètes de raisonnement ", Politix, 13, pp. 17-56.

HAMMER M., Champy J. (1993), Reengineering the Corporation. A Manifesto for Business Revolution, Harper Business, New York.

HARVEY D. (1990), The Condition of Postmodernity, Basil Blackwell, London.

HARVEY D. (2005), A Brief History of Neoliberalism, Oxford University Press, Oxford.

HARVEY D. (20I0), The Enigma of Capital and the Crises of Capitalism, Oxford University Press, Oxford-New York.

JENSEN M., MECKLING W. (1976), "Theory of the Firm: Managerial Behavior, Agency Costs, and Capital Structure", Journal of Financial Economics, 3, 4, pp. 305-36o.

KRIPPNER G. (2005), The Financialization of American Economy, Socio-Economic Review, 3, 2, pp. 173-208.

KRIPPNER G. (20II), Capitalizing on Crisis: The Political Origins of the Rise of Finance, Harvard University Press, Oxford.

LAZONICK W. (2010), "Innovative Business Models and Varieties of Capitalism: Financialization of the US Corporation", Business History Review, 84, 4, pp. 675-702.

LAZONICK W., O'SULLIVAN M. (2000), “Maximizing Shareholder Value: A New Ideology for Corporate Governance", Economy and Society, 29, I, pp. I3-35. 
MAGGI B. (200I), Le tendenze del post-fordismo: una interpretazione possibile tra teoria dell'organizzazione e sociologia del diritto, in V. Ferrari, P. Ronfani, S. Stabile (a cura di), Conflitti e diritti nella società transnazionale. Congresso internazionale di Sociologia del diritto, Courmayeur 1988, Franco Angeli, Milano, pp. 193-208.

MAGGI B. (2003), De l'agir organisationnel. Un point de vue sur le travail, le bien-être, l'apprentissage, Octarès, Toulouse.

MASINO G. (2005), Le imprese oltre il fordismo. Illusioni, retorica, realtà, Carocci, Roma.

MILBERG W. (2008), "Shifting Sources and Uses of Profits: Sustaining US Financialization with Global Value Chains", Economy and Society, 37, 3, pp. 420-45I.

ODIH P., KNIGHTS D. (2009), Organizzazioni come entità politiche, in D. Knights, H. Wilmott, R. Mercurio, G. Mangia (a cura di), Comportamento organizzativo, ISEDI, Torino, pp. 209-242.

PALLEY T. I. (2007), "Financialization: What It Is and Why It Matters", Working Paper No. 525, The Levy Economics Institute, Bard College, Washington DC.

PIORE M. J., SABEL C. F. (I984), The Second Industrial Divide, Basic Books, New York.

POWELL W. (1990), "Neither Markets nor Hierarchy: Network Forms of Organization", Research in Organizational Behavior, I2, pp. 295-336.

RADICE H. (20II), "Confronting the Crisis: A Class Analysis", Socialist Register, 47, pp. 2I-43.

SABEL C. F. (I989), Flexible Specialization and the Reemergence of Regional Economies, in P. Hirst, J. Zeitlin (eds.), Reversing Industrial Decline? Industrial Structure and Policy in Britain and Her Competitors, Berg, Oxford, pp. I7-70.

SALENTO A., MASINO G. (2013), La fabbrica della crisi. Finanziarizzazione delle imprese e declino del lavoro, Carocci, Roma.

SHORT J., DAVENPORT T. H. (I990), "The New Industrial Reengineering: Information Technology and Business Process Redesign", Sloan Management Review, 3I, pp. II-27. THRIFT N. (2005), Knowing Capitalism, Sage, London.

WILliAMSON 0. E. (ig86), The Economic Institutions of Capitalism: Firms, Markets, Relational Contractings, Free Press, New York.

WILMOTT H., ALVESSON M. (I992), Critical Management Studies, Sage, London.

WOMACK J. P., JONES D. T., ROOS D. (1990), The Machine that Changed the World, Rawson, New York. 